OPEN ACCESS

Edited by:

Hyo-Jun Ahn,

Gyeongsang National University,

South Korea

Reviewed by:

Jae-Kwang Kim,

Cheongju University,

South Korea

Mehmet Kadri Aydinol,

Middle East Technical University,

Turkey

*Correspondence: Berik Uzakbaiuly

berik.uzakbaiuly@nu.edu.kz;

Zhumabay Bakenov

zbakenov@nu.edu.kz

Specialty section:

This article was submitted to Electrochemical Energy Conversion and Storage,

a section of the journal Frontiers in Energy Research

Received: 16 August 2020 Accepted: 29 September 2020 Published: 09 November 2020

Citation:

Uzakbaiuly B, Mentbayeva A, Konarov A, Kurmanbayeva I, Zhang $Y$ and

Bakenov Z (2020) Evaluating Sulfur-

Composite Cathode Material with Lithiated Graphite Anode in Coin Cell and Pouch Cell Configuration. Front. Energy Res. 8:595481. doi: 10.3389/fenrg.2020.595481

\section{Evaluating Sulfur-Composite Cathode Material with Lithiated Graphite Anode in Coin Cell and Pouch Cell Configuration}

\author{
Berik Uzakbaiuly ${ }^{1}$, Almagul Mentbayeva ${ }^{1,2,3}$, Aishuak Konarov ${ }^{2,3}$, Indira Kurmanbayeva ${ }^{1,2}$, \\ Yongguang Zhang ${ }^{4}$ and Zhumabay Bakenov ${ }^{1,2,3 *}$ \\ ${ }^{1}$ National Laboratory Astana, Nazarbayev University, Nur-Sultan, Kazakhstan, ${ }^{2}$ Department of Chemical and Materials \\ Engineering, Nazarbayev University, Nur-Sultan, Kazakhstan, ${ }^{3}$ Institute of Batteries LLC, Nur-Sultan, Kazakhstan, ${ }^{4}$ Research \\ Institute for Energy Equipment Materials, Hebei University of Technology, Tianjin, China
}

High-performance sulfur-composite cathode material, sulfur/polyacrylonitrile/ketjen black, was prepared by simple mixing and low-temperature heat treatment route. The cell made of the composite cathode and anode from metallic lithium or lithiated graphite was assembled in coin cell configuration. Half-cells retained about $70 \%$ of their initial capacity of $1,270 \mathrm{mAh}^{-1}$ after 150 cycles, while full-cells retained about $85 \%$ of the initial capacity of $1,500 \mathrm{mAh} \mathrm{g}^{-1}$ for over 150 cycles. Since coin cells do not reflect the true performance of a practical cell, the cathode composite was assembled with lithiated graphite anode in a $45 \times 85 \times 6 \mathrm{~mm}^{3}$ pouch cell configuration. This cell retained about $81 \%$ of its initial capacity for over 100 cycles. At high cycling rates up to $1 \mathrm{C}$, the pouch cell demonstrated a moderate rate capability and exhibited good recovery and stable performance after high rate cycling. Also, the cell successfully passed safety tests such as overcharge, deep discharge, and mechanical short circuit tests.

Keywords: lithium sulfur battery, sulfur-composite cathode materials, Li-S coin and pouch cells, rechargeable battery, lithiated electrode for Li-S battery

\section{INTRODUCTION}

Li-ion batteries (LIBs) based upon nickel-rich layered transition metal oxide cathodes $\mathrm{LiNi}_{1-\mathrm{x}-\mathrm{y}} \mathrm{Mn}_{\mathrm{x}} \mathrm{Co}_{\mathrm{y}} \mathrm{O}_{2}(\mathrm{NMC}, \mathrm{x}+\mathrm{y}<0.5)$ and graphite anodes are ubiquitous cells of several battery manufacturers. LIBs deliver high energy density $\left(>200 \mathrm{Wh} \mathrm{kg}^{-1}\right)$ and stable cycle performance ( $>1,000$ cycles), as long as problems like flammable liquid electrolytes, overheating, extreme temperature failure, overcharge, and deep discharge are appropriately managed by designing a thorough battery management system (Rahimi-Eichi et al., 2013; Nitta et al., 2015). This, of course, along with increasing prices for nickel and cobalt, adds to the price of the battery at the pack level and the required progress toward the cost of energy storage $<100 \mathrm{USD} \mathrm{kWh}^{-1}$ for electric vehicles, unmanned aerial vehicles, and portable devices are still ongoing. In addition, in order to reach $500 \mathrm{Wh} \mathrm{kg}^{-1}$ energy density at the cell level, investigation of the possibilities of replacing graphite anode with Li-metal is one of the pursuits of many researchers (Albertus et al., 2017; Choudhury, 2019; Liu et al., 2019a; Yasin et al., 2019). However, the problems such as Li-metal consumption, dendrite formation, electrolyte contamination, and volume change upon cycling still have not been resolved entirely. 
In order to enhance electrochemical performance, compensate the battery cost, and ensure safety at the cell level, various technologies are under development such as nonflammable polymer electrolytes (Croce et al., 1998; Wang et al., 2019; Wei et al., 2019), solid electrolytes (Liu et al., 2019b; Zhao et al., 2019), lithium/sulfur (Li/S) batteries (Aurbach et al., 2009; Liang et al., 2016; Seh et al., 2016), and others (Girishkumar et al., 2010; Omampuliyur et al., 2015). Li/S batteries are considered as next-generation batteries, which offer a high theoretical energy density of $2,500 \mathrm{Wh} \mathrm{kg}^{-1}$ with a very competitive price at the cell level $\left(70 \mathrm{USD} \mathrm{kWh}^{-1}\right.$ ) (Hagen et al., 2015). Although several groups have claimed good capacity and cyclability with sulfur-composite cathode materials, many of them have used coin cell configuration whose properties cannot be translated into practical pouch cells (Cheng et al., 2017; Liu et al., 2019a). In coin cells, the electrolyte is overflooded (> $10 \mu \mathrm{L} \mathrm{mg}^{-1}$ of cathode), and the Li foil that is usually used as a counter electrode is very thick $(>250 \mu \mathrm{m})$, whereas in practical pouch cells, the electrolyte content should be limited and Li-metal should be as thin as possible in order to reach high energy densities of $500 \mathrm{Wh} \mathrm{kg}^{-1}$. In addition, uneven current distribution in the practical cell causes Li dendrites to grow, which in turn may short-circuit the cell and hinders its long-term operation (Cheng et al., 2017). Therefore, a newly developed cathode material, after testing in a coin cell, needs to be tested in a pouch cell configuration to verify its practicality.

One of the most popular ways of a sulfur cathode material preparation is a formation of a sulfur-carbon composite. For example, a multiwalled carbon nanotube/nano-S cathode exhibits excellent electrochemical performance, but it is composed of expensive MWCNT and nano-S (Yuan et al., 2009). Several sulfur/conductive polymer/conductive carbon ternary composites have been developed and offer an inexpensive alternative, yet their properties can be further optimized (Liang et al., 2016). For instance, polypyrrole-coated sulfur/ ketjen black $(\mathrm{S} / \mathrm{KB})$ with $1,047 \mathrm{mAh} \mathrm{g}^{-1}$ initial discharge capacity decays in the performance during cycling due to the dissolution of polysulfides (Nakamura et al., 2016). The composites of sulfur with conductive polymer-polyacrylonitrile have been intensely investigated because it exhibited a capability to accommodate the sulfur volume change upon cycling, prevent polysulfide dissolution, and act as conductivity enhancer (Wang et al., 2002; Peng et al., 2017). Moreover, sulfurized polyacrylonitrile composite offers stable specific capacity, which is very close to the theoretical value of elemental sulfur and the simpler reaction mechanism avoiding long-chain polysulfide reaction, and offers chemical compatibility with $\mathrm{LiPF}_{6}$-carbonate-based electrolyte with high Coulombic efficiency and low self-discharge (Zhang, 2014; Hara et al., 2015). Figure 1 shows the reaction mechanism of sulfur/ polyacrylonitrile (S/PAN) composite after the first and subsequent cycles, which has been proposed by Wang et al. (2018). The S-S bond is cleaved in the first discharge process, and subsequent S/PAN becomes conjugative with thiyl radical. This radical structure forms an ion-coordination bond which enables a fast Li-ion transfer mechanism. In this work, a mixture of sulfur/polyacrylonitrile/conductive carbon has been utilized to fabricate a composite cathode material that was evaluated in coin cell and pouch cell configuration. Testing in pouch cell configuration offers valuable insight into the feasibility of the composites for full-scale battery application. Here, we prepared sulfur/polyacrylonitrile/ketjen black (S/PAN/KB) composite by simple mixing of sulfur, $\mathrm{KB}$, and $\mathrm{PAN}$, followed by heat treatment in Ar environment. The preparation procedure is simple and offers opportunities for the most industrially suitable scale-up methods.

The successfully prepared S/PAN/KB composite cathode was tested in coin cell configuration both in half-cell configuration using Li-metal anode and in full-cell configuration using lithiated graphite as the anode. The full-cell configuration showed better cycling performance than the half-cell one because of a stable solid electrolyte interface (SEI) layer formed at the prelithiated graphite anode. The initial discharge capacity of the cell was about $1,500 \mathrm{mAh} \mathrm{g}^{-1}$, which is about $90 \%$ of the theoretical capacity of the sulfur anode, and the cell showed very stable electrochemical performance.

As the behavior of a cell in a coin cell configuration is not the true indication of practical battery performance, Li-metal free pouch cells of $2000 \mathrm{mAh}$ and 10,000 mAh capacities were constructed to conduct the tests in the most close to practical application conditions. On the verge of several sulfur-composite materials' development, our pouch cell revealed great promises and could deliver high-performance capabilities with the Coulombic efficiency of $100 \%$ over 100 cycles. The developed composite material is inexpensive, enables high utilization of sulfur, and is very suitable for pouch cell design.

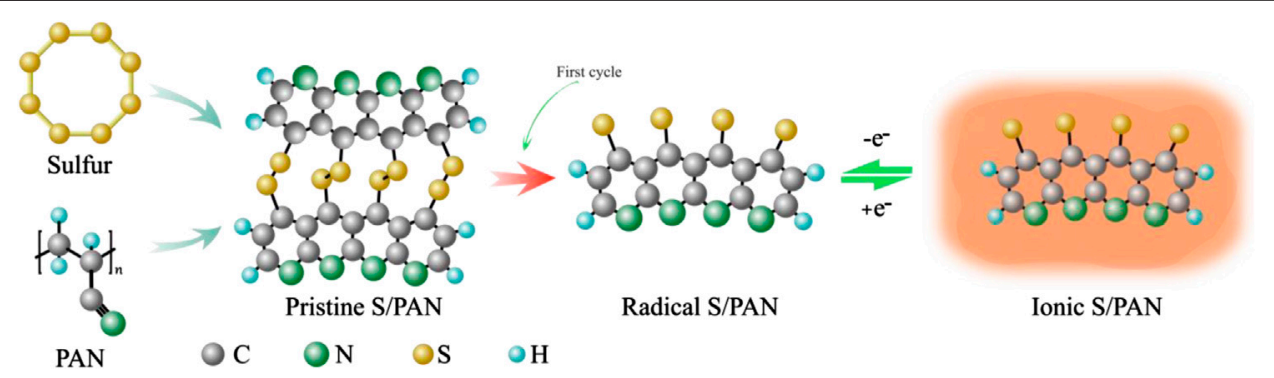

FIGURE 1 | S/PAN reaction mechanism with radical and ionic intermediates. Adapted with premission from Wang et al. (2018). Copyright (2018) American Chemical Society. 


\section{EXPERIMENTAL SECTION}

\section{Materials}

Sulfur (98\%, GOST 127.1, Tengizchevroil, Kazakhstan), polyacrylonitrile (average molecular weight 150,000, J\&K Scientific), ketjen black (Akzo Nobel), and natural graphite (Hohsen Corp.) were used as received without further purification.

\section{Material Synthesis and Cell Assembly}

Sulfur, PAN, and KB were mixed in a weight ratio of $4: 1: 1.5 \mathrm{wt} \%$ using ball-mill (Pulverisette 7, Fritsch Inc.) and heat-treated at $300^{\circ} \mathrm{C}$ for $3 \mathrm{~h}$ in a tubular furnace in argon to form a molecular level composite $\mathrm{S} / \mathrm{PAN} / \mathrm{KB}$. After heat treatment, the sulfur content in the S/PAN/KB composite cathode was about $47 \%$ as revealed by CHNS analysis (Vario Micro cube, Elementar Inc.). When a composite with a higher sulfur content value was prepared, the battery did not show good performance, and as a result, the S/PAN/KB composite prepared with a weight ratio of the components $4: 1: 1.5$ was chosen for further characterization and cell assembly (Konarov et al., 2014; Mentbayeva et al., 2016).

\section{Cell Assembly}

The cathode slurry was prepared by dispersing $80 \mathrm{wt} \%$ of S/PAN/ $\mathrm{KB}$ composite, $10 \mathrm{wt} \%$ of acetylene black (MTI, 99.5\% purity), and $10 \mathrm{wt} \%$ polyvinylidene fluoride (PVDF, Kynar, HSV900) in N-methyl-2-pyrrolidone (NMP) (Sigma-Aldrich, 99.5\% purity). The resulting slurry was drop-cast on aluminum foil (MTI) using the doctor blade technique. Afterward, the electrode sheet was vacuum-dried at $60^{\circ} \mathrm{C}$ for $12 \mathrm{~h}$. Coin type cells were assembled in a glovebox (MasterLab, MBraun), using lithium metal discs $(250 \mu \mathrm{m})$ as both counter (negative) and a reference electrode, porous polypropylene membrane as a separator (Celgard $₫ 2,400$ ), and $1 \mathrm{M} \mathrm{LiPF} 6$ solution in ethylene carbonate/dimethyl carbonate/diethylene carbonate (EC : DMC : DEC, a volume ratio of $1: 1: 1$, Targray) as a liquid electrolyte. The areal mass loading of the cathode was $\sim 2 \mathrm{mg} \mathrm{cm}^{-2}$ with the electrolyte to the sulfur ratio of $30 \mathrm{ml} \mathrm{g}^{-1}$ (Mentbayeva et al., 2016). For a full-cell preparation, graphite anode was used.

Slurry preparation for graphite anode was the same as the above-described method. Graphite $(80 \mathrm{wt} \%)$ was mixed with $10 \mathrm{wt} \%$ acetylene black and $10 \mathrm{wt} \%$ polyvinylidene fluoride in $\mathrm{N}$-methyl-2-pyrrolidone, and the resulting slurry was cast on copper foil and then vacuum-dried. In order to lithiate the graphite, coin type cells (CR2032) were assembled using Limetal as a counter electrode. After a few cycles, the charged cell was disassembled, and lithiated graphite was taken for further use. Graphite anode preparation for pouch cells was as follows. Double side coated electrodes were prepared by roll pressing single side graphite coated electrode and casting the graphite slurry on the other side followed by vacuum drying at $60^{\circ} \mathrm{C}$ for $12 \mathrm{~h}$ and roll pressing. Each side of the graphite anode was wetted with $20 \mu \mathrm{L} \mathrm{cm}^{-2}$ electrolyte and then sandwiched between two slides of Li foil and glass plates with applying a little pressure and placing into a glass container. The lithiated graphite preparation set was left in a glove box for $12 \mathrm{~h}$ and used for pouch cell assembly immediately after disassembling this set.
To assemble pouch cells, the electrode sheets with the dimensions $85 \times 45 \mathrm{~mm}^{2}$ for $2 \mathrm{Ah}$ pouch cells and $165 \times$ $135 \mathrm{~mm}^{2}$ for $10 \mathrm{Ah}$ pouch cells were used, and hence, vacuum mixer and vacuum coater were used in this case. Mass loading of sulfur was similar to that of the coin cell $\left(2-2.2 \mathrm{mg} \mathrm{cm}^{-2}\right)$, and the mass loading of graphite was $10-12 \mathrm{mg} \mathrm{cm}^{-2}$ on each side of the electrode, which corresponded to an areal capacity of $3 \mathrm{mAh} \mathrm{cm}^{-2}$. Pouch cells were assembled in the glovebox with 12 pairs of double side coated cathode and anode and then sealed in a pouch cell case under vacuum. All lithiation and cell assembly procedures were carried in an argon-filled glovebox (MasterLab, MBraun) with $\mathrm{O}_{2}$ and $\mathrm{H}_{2} \mathrm{O}$ values less than $0.1 \mathrm{ppm}$.

\section{Characterization}

Crystal structure analysis of the samples was carried out by X-ray diffraction (XRD, Rigaku SmartLab). The morphology of the materials was investigated using scanning electron microscopy (UHR FE-SEM SU9000, Hitachi Co.) with energy-dispersive spectroscopy (EDS), and the sulfur content was determined using chemical analysis (CHNS, Vario Micro cube, Elementar Inc.).

The electrochemical performance of the S/PAN/KB composite cathode was investigated using coin type (CR2032) and pouch cells. The cells were galvanostatically cycled at different current densities in a potential range of $1.0-3.0 \mathrm{~V}$ vs. $\mathrm{Li}^{-} \mathrm{Li}^{+}$on a multichannel battery tester (BT-2000, Arbin Instruments Inc.). Specific capacity and current density were calculated based on the weight of sulfur in the electrode. Cyclic voltammetry $(\mathrm{CV})$ was conducted over a potential range from 1 to $3 \mathrm{Vvs}$. $\mathrm{Li}^{2} / \mathrm{Li}^{+}$at a scan rate of $0.1 \mathrm{mV} \mathrm{s}^{-1}$. All electrochemical measurements were carried out at room temperature.

\section{RESULTS AND DISCUSSION}

As mentioned above, the S/PAN/KB composite with $47 \mathrm{wt} \% \mathrm{~S}$ was chosen for further characterization. The morphology of the S/PAN/KB cathode composite was studied by SEM. As can be seen in Figure 2, sulfur, nitrogen, and carbon distribution in the $\mathrm{S} / \mathrm{PAN} / \mathrm{KB}$ composite is very homogeneous, enabling electronically conductive media around low conductive sulfur. It can be seen that the composite has a particle size around $250 \mathrm{~nm}$.

XRD data showed one broad peak at $2 \theta=25^{\circ}$, which revealed that the composite is amorphous in structure. This is in agreement with other reports which show the embedding of $S$ into PAN structure (Wang et al., 2002; Konarov et al., 2014; Mentbayeva et al., 2016; Kalybekkyzy et al., 2019).

Charge/discharge profiles and cycling performance of the halfcell coin cell are presented in Figures $\mathbf{3 A}, \mathbf{B}$, respectively. The initial discharge capacity of the cell at $0.2 \mathrm{C}$ was about $1700 \mathrm{mAh} \mathrm{g}^{-1}$, which after an intrinsic initial irreversible capacity drop stabilized around $1,300 \mathrm{mAh} \mathrm{g}^{-1}$ for 100 cycles (Hara et al., 2015; Nakamura et al., 2016; Wang et al., 2018). The low potential discharge plateau at the first cycle $(\Delta \mathrm{V} \sim-0.35 \mathrm{~V})$ and large initial discharge capacity is typical behavior for sulfurized polyacrylonitrile composite materials (Wang et al., 

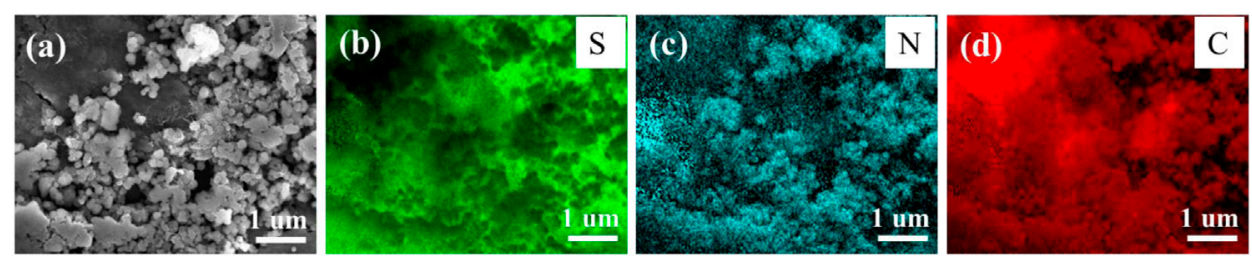

FIGURE 2 | (A) SEM-EDS image of S/PAN/KB composite, (B) sulfur, (C) nitrogen, and (D) carbon mapping of the composite.
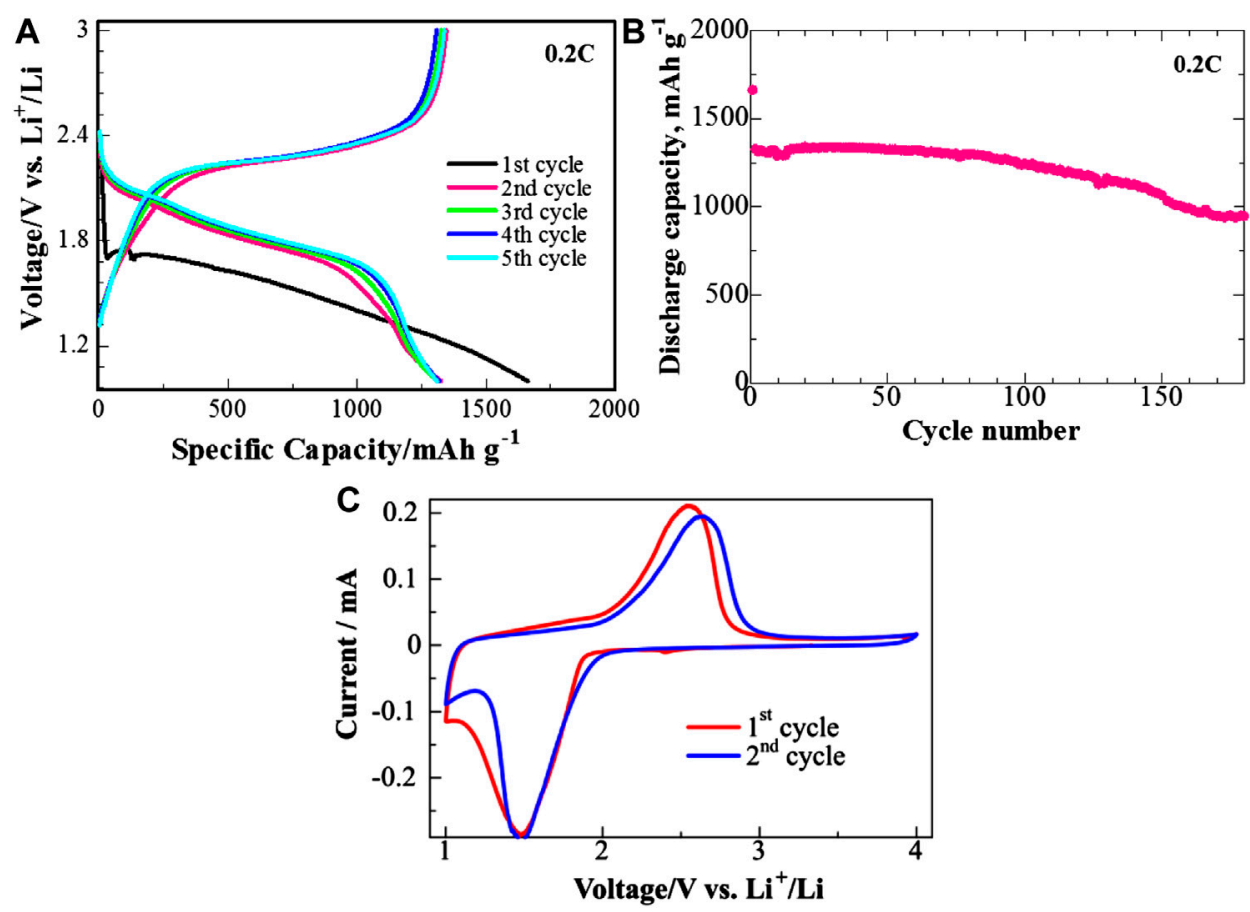

FIGURE 3 | (A) Charge/discharge profiles, (B) cyclability, and (C) cyclic voltammetry of the half-cell with S/PAN/KB cathode at 0.2 C. Coin type cells.

2018). After 150 cycles, the cells retained $70 \%$ of their initial discharge capacity, which demonstrates high cycle stability of the prepared composite cathode. The CV curves of the half-cell demonstrated one broad reduction peak around $1.5 \mathrm{~V}$ vs. Li/ $\mathrm{Li}^{+}$in the first cycle which shifts to higher potentials upon further cycling and one broad oxidation peak around $2.5 \mathrm{~V}$. This is typical behavior of the S/PAN-based cathode materials (Kalybekkyzy et al., 2019).

The half-cell exhibits a moderate rate capability, as can be seen in Figure 4. At $0.5 \mathrm{C}\left(\sim 800 \mathrm{~mA} \mathrm{~g}^{-1}\right)$, the discharge capacity around $1,200 \mathrm{mAh} \mathrm{g}^{-1}$ was observed, and when the cycling rate was returned back to a lower $\mathrm{C}$ rate of $0.2 \mathrm{C}\left(\sim 300 \mathrm{~mA} \mathrm{~g}^{-1}\right)$, the capacity was fully recovered, which means that this composite cathode can be used at different current densities.

The full-cell exhibited and enhanced cycling performance compared to the half-cell. Figure $\mathbf{5 A}$ illustrates charge/ discharge profiles of the S/PAN/KB cathode composite assembled in the full-cell (lithium-ion) configuration, and it

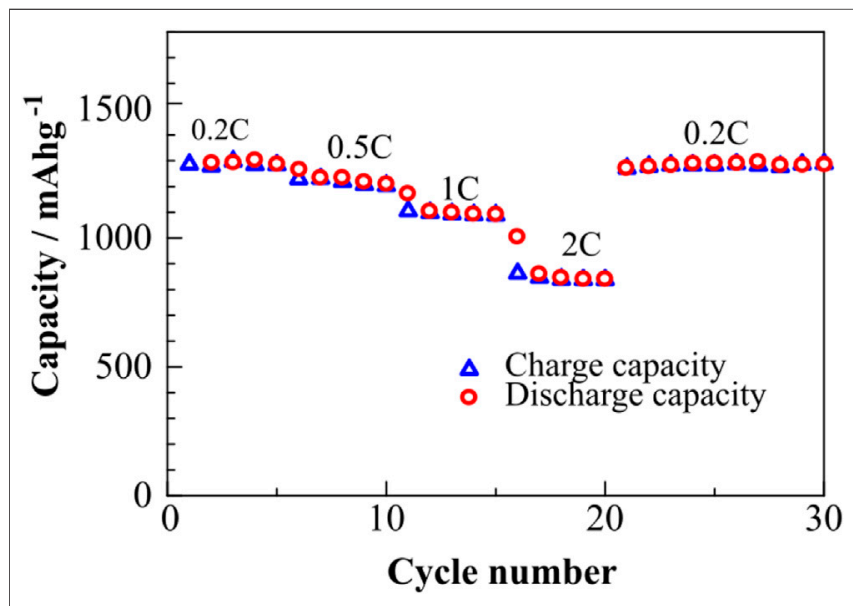

FIGURE 4 | Rate capability of half-cell containing S/PAN/KB composite assembled with Li-metal $\left(0.2 \mathrm{C}=300 \mathrm{~mA} \mathrm{~g}^{-1}\right.$ and $\left.0.5 \mathrm{C}=800 \mathrm{~mA} \mathrm{~g}^{-1}\right)$. 

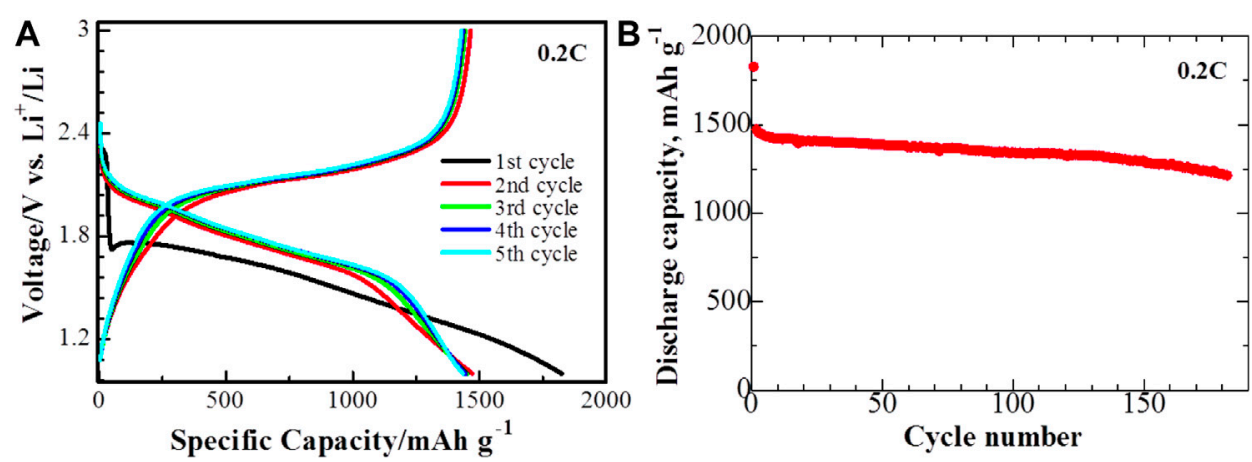

FIGURE 5 | (A) Charge/discharge profiles and (B) cyclability of S/PAN/KB full-cell at 0.2 C.

presents a very similar shape and tendency with the half-cell (with lithium metal anode) counterpart. Comparing the data of Figure $\mathbf{3 B}$ and $\mathbf{5 B}$, one can see that lithium-ion cell shows even better cycling performance than the Li-metal cell. This superior performance can be attributed to the fact that, with the lithiated graphite anode, a more stable SEI layer is formed, which relieves the capacity loss. Comparing Nyquist plots of half and full-cell, one can note that the full-cell exhibits more stable interfacial resistance than the half-cell (Supplementary Figure S1). Wu et al. (2018) have also observed similar behavior for halfand full-cell Li-S batteries with a customized ether-based electrolyte. In their work, an $\mathrm{S}-\mathrm{Li}_{\mathrm{x}} \mathrm{C}$ full-cell was prepared, which showed a discharge capacity of $900 \mathrm{mAh} \mathrm{g}^{-1}$ after 400 cycles. Our full-cell in a coin cell version with a commercial carbonate-based electrolyte without any additives or modifications shows very stable performance for the initial 150 cycles $\left(\sim 1,500 \mathrm{mAh}(\mathrm{g}-\mathrm{S})^{-1}\right)$.

Various groups have reported full-cell configuration such as S-Li-Si (Ye et al., 2017), Li 2 S-Si (Yang et al., 2010), $\mathrm{Li}_{2} \mathrm{~S}-\mathrm{C}$ (Bresser et al., 2013; Jeong et al., 2013), and $\mathrm{Li}_{2} \mathrm{~S}-\mathrm{Sn}$ (Hassoun et al., 2011) using coin cell configuration. However, a cathode preparation method with mixing and heat treatment developed in this work presents a simple and industrially scalable technique for pouch cell preparation.

Among the works reported on the fabrication of Li-S pouch cells, the best performing full-cell based on S-C cathode, Si-C anode, and LTFSI electrolyte has achieved a specific capacity of $\sim 500 \mathrm{mAh} \mathrm{g}^{-1}$ after 400 cycles (Kang et al., 2016). In addition, OXIS energy claimed to have developed $\sim 15 \mathrm{Ah} / 400 \mathrm{Wh} \mathrm{kg}^{-1} \mathrm{Li}-$ $\mathrm{S}$ pouch cells (Li-metal anode and assembled with ether electrolyte) with a cycle life of 100 cycles (Fotouhi et al., 2017). Pouch cell with $\mathrm{LiPF}_{6}$ electrolyte was fabricated using $\mathrm{S}-\mathrm{C}$ composite electrode material with an initial discharge capacity of $1,000 \mathrm{mAh} \mathrm{g}^{-1}$. However, no information about the cyclability of the cell was reported (Li et al., 2018). Here, we report the first practical pouch cell assembled in carbonate-based electrolytes with very stable performance.

Figure 6A shows the initial CV curve of a $2 \mathrm{Ah}$ pouch cell at the scan rate of $0.1 \mathrm{mV} \mathrm{s}^{-1}$. There is one broad reduction peak at $1.2 \mathrm{~V}$ and one oxidation peak at $2.6 \mathrm{~V}$ at the first cycle, which shifted toward a higher potential at the following cycle (dashed lines). The long-chain sulfur reaction mechanism is absent or very limited in S/PAN structure, and thus lithium polysulfides are merely formed in the electrolyte (Wang et al., 2018). This makes these systems very stable upon cycling. The CV data confirm that the pouch cell reaction mechanism reproduces the tendencies and behavior of those observed for the coin cell. To investigate the stability of the pouch cell in a wider potential range, overcharge and deep discharge tests were done by $\mathrm{CV}$ screening of the same cell in Figure 6A between 0.1 and $4.0 \mathrm{~V}$ (the cycles three to five, solid lines). Data shown in Figure 6A confirm that still only one oxidation and one reduction peaks appear in this wide potential range, except during the charge stage when the current starts to rise again around $4 \mathrm{~V}$. This might be related to corrosion of a current collector ( $\mathrm{Al}$ for cathode) after $4 \mathrm{~V}$. However, the $\mathrm{CV}$ curves are reproducible during the cycles, which confirms sufficient stability of the system even during overcharge and deep discharge operations.

Figure 6B shows the charge/discharge potential profiles of the pouch cell at $0.1 \mathrm{C}$, and the typical behavior of sulfurized polyacrylonitrile was observed in this case as well (Wang et al., 2018). In the pouch cell, we had 24 layers of electrodes, which were placed in parallel to each other. The amount of the material in a pouch cell is much larger than in a coin cell; however, the geometry of the pouch cell is more preferable for current flow as it can be seen from the impedance spectroscopy results. The semicircle is very small in the case of a pouch cell, which indicates small resistance of the system (Supplementary Figure S2). Indeed, it is not comparable with coin cell (Supplementary Figure S2, inset), since the cells are very different in their structures and sizes. It should be noted that the applied areal current to the cell is estimated to be $160 \mathrm{~mA}$, which is much larger than that of the coin cell counterparts (0.5-5 mA) (Cheng et al., 2017).

The cycling performance of the pouch cell is stable, as shown in Figure 6C. It delivers a high discharge capacity of $2000 \mathrm{mAh}$ in the second cycle at $0.1 \mathrm{C}$. The cell could maintain $81 \%$ of its capacity $(\sim 1,630 \mathrm{mAh})$ after 100 cycles, as shown in Figure 6C, which is the highest reported value for Li-S full-cell assembled in the carbonate-based electrolyte. Capacity fading (or increase in the cell resistance) is attributed to the slight dissolution of $S$ into the electrolyte. The system exhibited a high Coulombic efficiency 

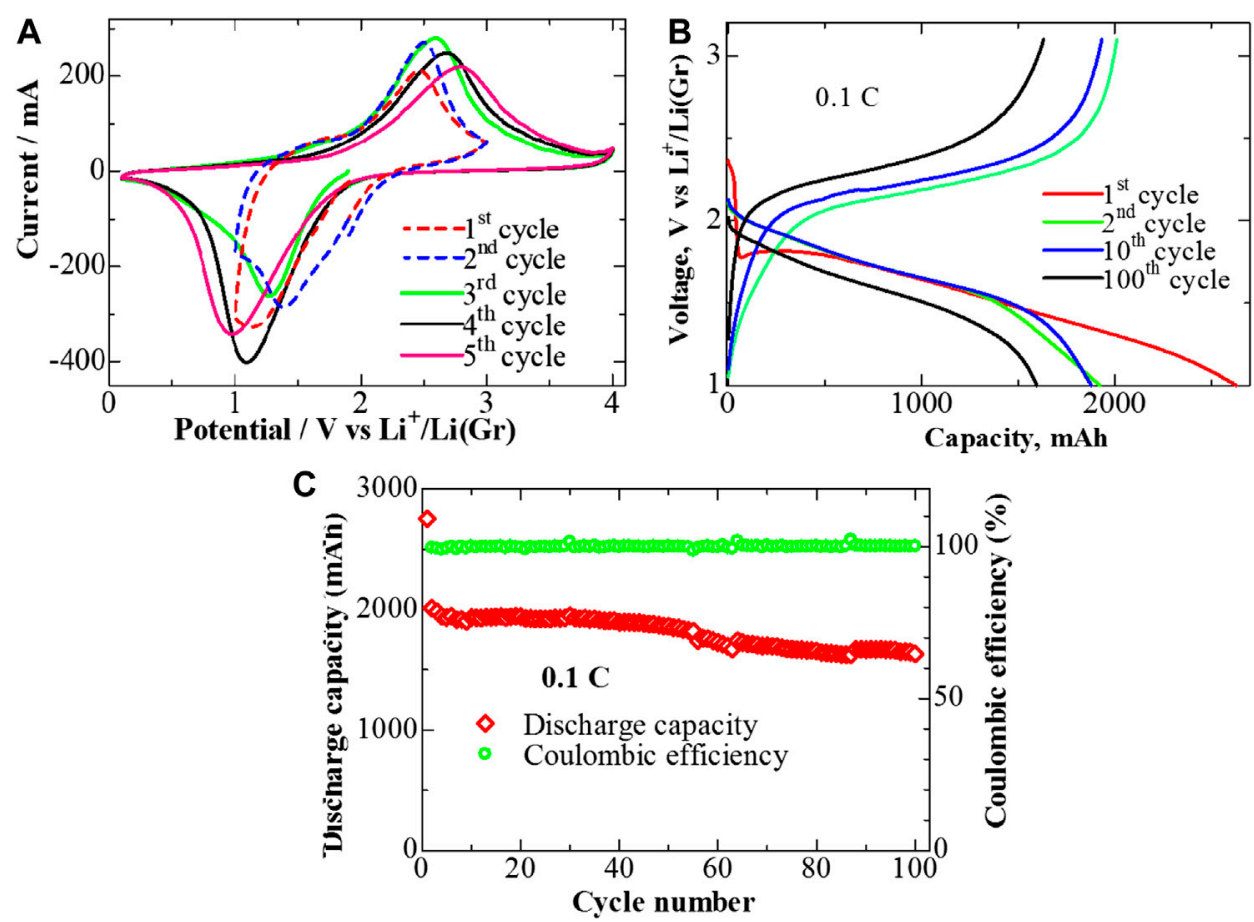

FIGURE 6 | CV curves at a scan rate $0.1 \mathrm{~V} \mathrm{~s}^{-1}$ within potential windows (A) $1-3 \mathrm{~V}$ and (B) $0.1-4 \mathrm{~V} \mathrm{vs.} \mathrm{Li/Li+}$; (B) charge/discharge profile; and (C) cyclability of the pouch cell within cutoff potentials $1-3 \mathrm{~V}$ vs. Li/Li+

of about $100 \%$ over 100 cycles, which could be attributed to the shuttle effect suppression in the hierarchical mesoporous and macroporous structure of the ternary composite prepared in this work.

Similar discharge characteristics could be observed for a $10 \mathrm{Ah}$ pouch cell with the electrode areal dimensions of $135 \times 165 \mathrm{~mm}$. The cell could deliver a capacity of $10,640 \mathrm{mAh}$ with a $0.1 \mathrm{C}$ rate (Supplementary Figure S3). These results show the scalability of this system from the coin cell to the pouch cell configuration.

The rate capability studies of $2 \mathrm{Ah}$ pouch cells have been carried out as presented in Figure 7A. It was galvanostatically charged at $0.2 \mathrm{C}$ and discharged at various discharge rates up to $2 \mathrm{C}$. At $0.1 \mathrm{C}$ rate, the cell exhibited an initial discharge capacity of $1950 \mathrm{mAh}$, at $0.2 \mathrm{C}$ it exhibited an initial discharge capacity of $1750 \mathrm{mAh}$, and at $0.5 \mathrm{C}$, it exhibited an initial discharge capacity of $850 \mathrm{mAh}$. Although these values decreased gradually with the cycling rate, a reversible capacity of $280 \mathrm{mAh}$ could be achieved even at $1 \mathrm{C}$ rate, indicating a good rate performance of the system. This is attributed to a unique sulfur reaction mechanism with polyacrylonitrile. After cycling at $2 \mathrm{C}$ with a delivered capacity of $50 \mathrm{mAh}$, the cell could recover its reversible capacity of about $1700 \mathrm{mAh}$ when it was further cycled at $0.1 \mathrm{C}$. This is a good indicator of performance for practical pouch cells.

In addition, the self-discharge behavior studies of this cell were carried out, the results of which are shown in Figure 7B. After charging to $3 \mathrm{~V}$, the cell retained a potential above $2 \mathrm{~V}$ for 30 days, which indicates good stability and low self-discharge of only $0.7 \mathrm{mV} \mathrm{day}^{-1}$. In addition, overcharge, deep discharge, and short circuit tests have been carried out for the $2 \mathrm{Ah}$ pouch cell
(Supplementary Figure S4). During the tests, no seal leaks, fire, or explosion was detected and/or observed, but there was a swelling of the battery during overcharge (Supplementary Figure S4(a)). Therefore, it can be confirmed that our pouch cells comply with the safety requirements for lithium-ion batteries. In order to test the feasibility of the cell for potential device applications, a battery stack-a prototype of rechargeable batteries for a radio phone and drone-was assembled from 5 pouch cells of the dimensions of $85 \times 45 \times 6 \mathrm{~mm}^{3}$ as shown in Figure 8A. Two Ah pouch cells of the same capacity were connected in series to obtain the required stack voltage of $10 \mathrm{~V}\left(\sim 170 \mathrm{Wh} \mathrm{L}^{-1}\right)$. As shown in Figure $8 \mathbf{B}$, the battery prototype exhibits a stable charge/discharge profile, and an average discharge potential was around $10 \mathrm{~V}$ suitable for the applications mentioned.

\section{CONCLUSION}

In conclusion, $\mathrm{S} / \mathrm{PAN} / \mathrm{KB}$ cathode composite was prepared by a very simple method of mixing and heat treatment. An optimized (heat treatment at $300^{\circ} \mathrm{C}$ for $3 \mathrm{~h}$ ) S/PAN/KB cathode composite delivered a high capacity of $1,500 \mathrm{mAh} / \mathrm{g}$ when assembled with lithiated graphite in coin cell configuration. All cell components used for cell assembly, including carbonate electrolyte, were commercially available and were not customized or modified and are thus of a low cost. In order to show the practicality of the developed composite cathode and proposed approaches in this work, pouch cells with the cathode composite and lithiated 

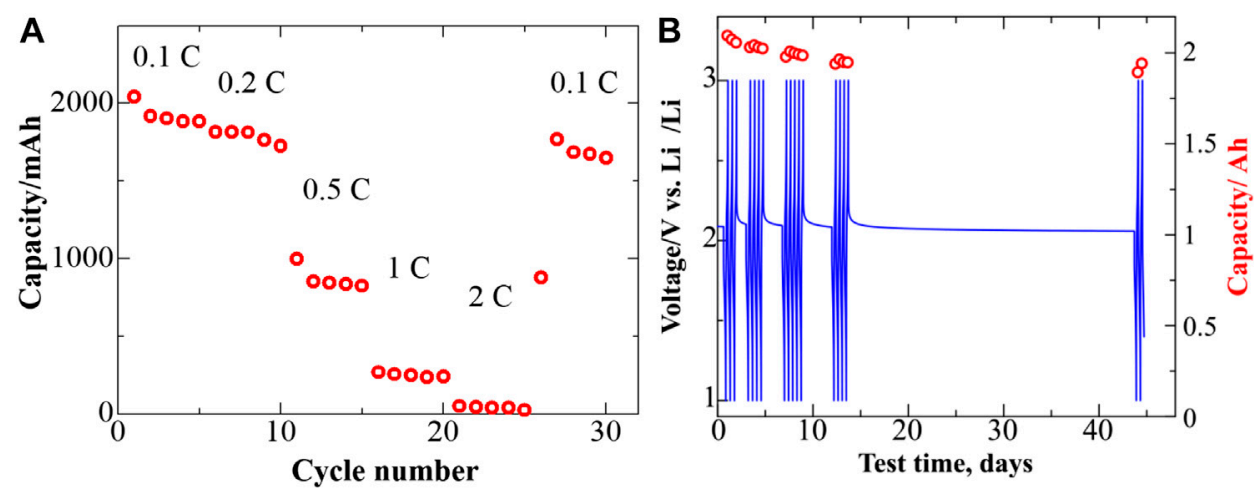

FIGURE 7 | (A) Rate performance and (B) self-discharge of 2 Ah Li-S pouch cell.
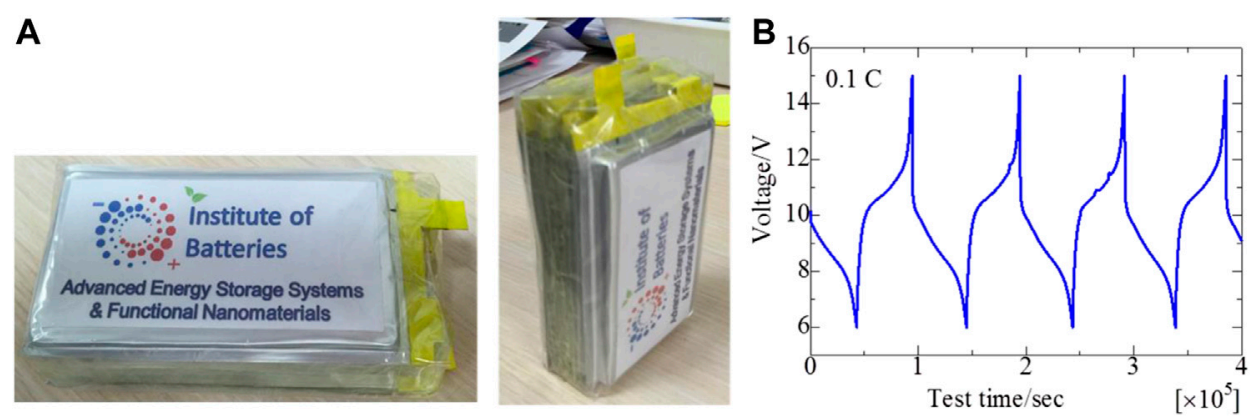

FIGURE 8 | (A) Photos of battery stack from five 2 Ah pouch cells connected in series and (B) the stack's cyclability.

graphite were assembled. The cell showed a stable capacity of $2000 \mathrm{mAh}$ with $100 \%$ Coulombic efficiency over 100 cycles, and it has successfully passed the safety tests required for commercial batteries. This work demonstrates very feasible results for a Li-S practical full-cell and promising results toward its commercialization.

\section{DATA AVAILABILITY STATEMENT}

All datasets presented in this study are included in the article/ Supplementary Material.

\section{AUTHOR CONTRIBUTIONS}

$\mathrm{YZ}, \mathrm{AM}, \mathrm{IK}, \mathrm{AK}$, and $\mathrm{ZB}$ developed the project idea. $\mathrm{ZB}$ supervised the work. $\mathrm{BU}, \mathrm{AM}, \mathrm{AK}, \mathrm{IK}, \mathrm{YZ}$, and $\mathrm{ZB}$ contributed to discussion and manuscript writing. BU, AM, $\mathrm{AK}, \mathrm{IK}$, and $\mathrm{YZ}$ contributed to experimental work.

\section{FUNDING}

This work was supported by the Subproject \#157-2013 funded under the Technology Commercialization Project by the World Bank and the Government of the Republic of Kazakhstan and the Targeted Program from the Ministry of Education and Science of Kazakhstan BR05236524 "Innovative materials and systems for energy conversion and storage.”

\section{ACKNOWLEDGMENTS}

The authors thank Professor Izumi Taniguchi from Tokyo Institute of Technology, Japan, for assistance in conducting the SEM-EDS measurements.

\section{SUPPLEMENTARY MATERIAL}

The Supplementary Material for this article can be found online at: https://www.frontiersin.org/articles/10.3389/fenrg.2020.595481/ full\#supplementary-material 


\section{REFERENCES}

Albertus, P., Babinec, S., Litzelman, S., and Newman, A. (2017). Status and challenges in enabling the lithium metal electrode for high-energy and low-cost rechargeable batteries. Nat. Energy. 3 (1), 16-21. doi:10.1038/s41560-017-0047-2

Aurbach, D., Pollak, E., Elazari, R., Salitra, G., Kelley, C. S., and Affinito, J. (2009). On the surface chemical aspects of very high energy density, rechargeable Lisulfur batteries. J. Electrochem. Soc. 156 (8), 694-702. doi:10.1149/1.3148721

Bresser, D., Passerini, S., and Scrosati, B. (2013). Recent progress and remaining challenges in sulfur-based lithium secondary batteries-a review. Chem. Commun. 49 (90), 10545-10562. doi:10.1039/c3cc46131a

Cheng, X.-B., Yan, C., Huang, J.-Q., Li, P., Zhu, L., Zhao, L., et al. (2017). The gap between long lifespan Li-S coin and pouch cells: the importance of lithium metal anode protection. Energy Storage Mater. 6, 18-25. doi:10.1016/j.ensm.2016.09.003

Choudhury, S. (2019). "A highly reversible room-temperature lithium metal battery based on cross-linked hairy nanoparticles," in Rational design of nanostructured polymer electrolytes and solid-liquid Interphases for lithium batteries. (Cham, Switzerland: Springer International Publishing), 35-57.

Croce, F., Appetecchi, G. B., Persi, L., and Scrosati, B. (1998). Nanocomposite polymer electrolytes for lithium batteries. Nature 394 (6692), 456-458. doi:10.1038/28818

Fotouhi, A., Auger, D. J., O’Neill, L., Cleaver, T., and Walus, S. (2017). Lithiumsulfur battery technology readiness and applications-a review. Energies 10 (12), 1937. doi:10.3390/en10121937

Girishkumar, G., McCloskey, B., Luntz, A. C., Swanson, S., and Wilcke, W. (2010). Lithium-air battery: promise and challenges. J. Phys. Chem. Lett. 1 (14), 2193-2203. doi:10.1021/jz1005384

Hagen, M., Hanselmann, D., Ahlbrecht, K., Maça, R., Gerber, D., and Tübke, J. (2015). Lithium-sulfur cells: the gap between the state-of-the-art and the requirements for high energy battery cells. Adv. Energy Mater. 5 (16), 1401986. doi:10.1002/aenm.201401986

Hara, T., Konarov, A., Mentbayeva, A., Kurmanbayeva, I., and Bakenov, Z. (2015). High mass-loading of sulfur-based cathode composites and polysulfides stabilization for rechargeable lithium/sulfur batteries. Front. Energy Res. 3, 7-12. doi:10.3389/fenrg.2015.00022

Hassoun, J., Sun, Y.-K., and Scrosati, B. (2011). Rechargeable lithium sulfide electrode for a polymer tin/sulfur lithium-ion battery. J. Power Sources. 196 (1), 343-348. doi:10.1016/j.jpowsour.2010.06.093

Jeong, S., Bresser, D., Buchholz, D., Winter, M., and Passerini, S. (2013). Carbon coated lithium sulfide particles for lithium battery cathodes. J. Power Sources. 235, 220-225. doi:10.1016/j.jpowsour.2013.01.084

Kalybekkyzy, S., Mentbayeva, A., Kahraman, M. V., Zhang, Y., and Bakenov, Z. (2019). Flexible S/DpAN/KB nanofiber composite as binder-free cathodes for Li-S batteries. J. Electrochem. Soc. 166 (3), A5396-A5402. doi:10.1149/2. 0571903jes

Kang, H. S., Park, E., Hwang, J.-Y., Kim, H., Aurbach, D., Rosenman, A., et al. (2016). A scaled-up lithium (Ion)-sulfur battery: newly faced problems and solutions. Adv. Mater. Technol. 1 (6). doi:10.1002/admt.201670027

Konarov, A., Gosselink, D., Doan, T. N. L., Zhang, Y., Zhao, Y., and Chen, P. (2014). Simple, scalable, and economical preparation of sulfur-PAN composite cathodes for Li/S batteries. J. Power Sources. 259, 183-187. doi:10.1016/j. jpowsour.2014.02.078

Li, X., Banis, M., Lushington, A., Yang, X., Sun, Q., Zhao, Y., et al. (2018). A highenergy sulfur cathode in carbonate electrolyte by eliminating polysulfides via solid-phase lithium-sulfur transformation. Nat. Commun. 9 (1), 1-10. doi:10. 1038/s41467-018-06877-9

Liang, J., Sun, Z.-H., Li, F., and Cheng, H.-M. (2016). Carbon materials for Li-S batteries: functional evolution and performance improvement. Energy Storage Mater. 2, 76-106. doi:10.1016/j.ensm.2015.09.007

Liu, J., Bao, Z., Cui, Y., Dufek, E. J., Goodenough, J. B., Khalifah, P., et al. (2019a). Pathways for practical high-energy long-cycling lithium metal batteries. Nat. Energy. 4 (3), 180-186. doi:10.1038/s41560-019-0338-x

Liu, Q., Yu, Q., Li, S., Wang, S., Zhang, L., Cai, B., et al. (2019b). Safe LAGP-based all solid-state Li metal batteries with plastic super-conductive interlayer enabled by in-situ solidification. Energy Storage Mater. 25, 613-620. doi:10.1016/j.ensm. 2019.09.023

Mentbayeva, A., Belgibayeva, A., Umirov, N., Zhang, Y., Taniguchi, I., Kurmanbayeva, I., et al. (2016). High performance freestanding composite cathode for lithium-sulfur batteries. Electrochim. Acta. 217, 242-248. doi:10. 1016/j.electacta.2016.09.082
Nakamura, N., Wu, Y., Yokoshima, T., Nara, H., Momma, T., and Osaka, T. (2016). Film properties of electropolymerized polypyrrole for a sulfur/ketjenblack cathode in lithium secondary batteries. J. Electrochem. Soc. 163 (5), A683-A689. doi:10.1149/2.0731605jes

Nitta, N., Wu, F., Lee, J. T., and Yushin, G. (2015). Li-ion battery materials: present and future. Mater. Today. 18, 252-264 doi:10.1016/j.mattod.2014.10.040

Omampuliyur, R. S., Bhuiyan, M., Han, Z., Jing, Z., Li, L., Fitzgerald, E. A., et al. (2015). Nanostructured thin film silicon anodes for Li-ion microbatteries. J. Nanosci. Nanotechnol. 15 (7), 4926-4933. doi:10.1166/jnn.2015.9831

Peng, H., Wang, X., Zhao, Y., Tan, T., Mentbayeva, A., Bakenov, Z., et al. (2017). Enhanced electrochemical performance of sulfur/polyacrylonitrile composite by carbon coating for lithium/sulfur batteries. J. Nanoparticle Res. 19 (10), 348. doi:10.1007/s11051-017-4049-6

Rahimi-Eichi, H., Ojha, U., Baronti, F., and Chow, M.-Y. (2013). Battery management system: an overview of its application in the smart grid and electric vehicles. EEE Ind. Electron. Mag. 7 (2), 4-16. doi:10.1109/mie.2013.2250351

Seh, Z. W., Sun, Y., Zhang, Q., and Cui, Y. (2016). Designing high-energy lithiumsulfur batteries. Chem. Soc. Rev. 45 (20), 5605-5634. doi:10.1039/c5cs00410a

Wang, J., Yang, J., Xie, J., and Xu, N. (2002). A novel conductive polymer-sulfur composite cathode material for rechargeable lithium batteries. Adv. Mater. 14 (13), 963-965. doi:10.1002/1521-4095(20020705)14:13/14<963::aidadma963>3.0.co;2-p

Wang, Q., Zhang, H., Cui, Z., Zhou, Q., Shangguan, X., Tian, S., et al. (2019). Siloxane-based polymer electrolytes for solid-state lithium batteries. Energy Storage Mater. 23, 466-490. doi:10.1016/j.ensm.2019.04.016

Wang, W., Cao, Z., Elia, G. A., Wu, Y., Wahyudi, W., Abou-Hamad, E., et al. (2018). Recognizing the mechanism of sulfurized polyacrylonitrile cathode materials for Li-S batteries and beyond in Al-S batteries. ACS Energy Lett. 3 (12), 2899-2907. doi:10.1021/acsenergylett.8b01945

Wei, Z., Zhang, Z., Chen, S., Wang, Z., Yao, X., Deng, Y., et al. (2019). UV-cured polymer electrolyte for $\mathrm{LiNi} 0.85 \mathrm{Co} 0.05 \mathrm{Al} 0.1 \mathrm{O}_{2} / / \mathrm{Li}$ solid state battery working at ambient temperature. Energy Storage Mater. 22, 337-345. doi:10.1016/j. ensm.2019.02.004

Wu, Y., Momma, T., Yokoshima, T., Nara, H., and Osaka, T. (2018). High performance sulfur graphite full cell for next generation sulfur Li-ion battery. J. Power Sources. 388, 5-10. doi:10.1016/j.jpowsour.2018.03.051

Yang, Y., McDowell, M. T., Jackson, A., Cha, J. J., Hong, S. S., and Cui, Y. (2010). New nanostructured Li2S/Silicon rechargeable battery with high specific energy. Nano Lett. 10 (4), 1486-1491. doi:10.1021/nl100504q

Yasin, G., Arif, M., Mehtab, T., Lu, X., Yu, D., Muhammad, N., et al. (2019). Understanding and suppression strategies toward stable Li metal anode for safe lithium batteries. Energy Storage Mater. 25, 644-678. doi:10.1016/j.ensm.2019. 09.020

Ye, R., Bell, J., Patino, D., Ahmed, K., Ozkan, M., and Ozkan, C. S. (2017). Advanced sulfur-silicon full cell architecture for lithium ion batteries. Sci. Rep. 7 (1), 1-10. doi:10.1038/s41598-017-17363-5

Yuan, L., Yuan, H., Qiu, X., Chen, L., and Zhu, W. (2009). Improvement of cycle property of sulfur-coated multi-walled carbon nanotubes composite cathode for lithium/sulfur batteries. J. Power Sources. 189 (2), 1141-1146. doi:10.1016/j. jpowsour.2008.12.149

Zhang, S. (2014). Understanding of sulfurized polyacrylonitrile for superior performance lithium/sulfur battery. Energies 7 (7), 4588-4600. doi:10.3390/ en7074588

Zhao, C.-Z., Zhao, B.-C., Yan, C., Zhang, X.-Q., Huang, J.-Q., Mo, Y., et al. (2019). Liquid phase therapy to solid electrolyte-electrode interface in solid-state $\mathrm{Li}$ metal batteries: a review. Energy Storage Mater. 24, 75-84. doi:1016/j.ensm. 2019.07.026

Conflict of Interest: The authors declare that the research was conducted in the absence of any commercial or financial relationships that could be construed as a potential conflict of interest.

Copyright (c) 2020 Uzakbaiuly, Mentbayeva, Konarov, Kurmanbayeva, Zhang and Bakenov. This is an open-access article distributed under the terms of the Creative Commons Attribution License (CC BY). The use, distribution or reproduction in other forums is permitted, provided the original author(s) and the copyright owner(s) are credited and that the original publication in this journal is cited, in accordance with accepted academic practice. No use, distribution or reproduction is permitted which does not comply with these terms. 